\title{
Community structure and comparative analysis of the woody component of a cerrado remnant in Southeastern Brazil
}

\author{
Katia Losano Ishara ${ }^{1}$ and Rita de Cassia Sindrônia Maimoni-Rodella $a^{2,3}$
}

Received: 30.12.2009; accepted: 22.04.2010

\begin{abstract}
Community structure and comparative analysis of the woody component of a cerrado remnant in Southeastern Brazil). The aims of the present work were to carry out a floristic-structural study of the shrubby-arboreal component of a savanna fragment (cerrado sensu stricto) in São Paulo State, Southeastern Brazil, and to compare with other areas. Twentyone plots of $250 \mathrm{~m}^{2}$ each were delimited and plants with stem basal diameter equal or superior to $3 \mathrm{~cm}$ were included in the sampling. The recorded individuals corresponded to 3,062 and 58 species belonging to 34 families were registered. Asteraceae had the largest number of species (seven), followed by Fabaceae and Myrtaceae (five each). The most important species were Tibouchina stenocarpa and Anadenanthera falcata. The floristic composition of the study area indicates that it might be considered a transition from cerrado to seasonal semi-deciduous forest. The comparison with other surveys indicates floristic-structural heterogeneity of these cerrado areas and the multivariate analysis showed that areas grouped according to their geographical position and soil type.
\end{abstract}

Key words: phytosociology, savanna, similarity

RESUMO - (Estrutura da comunidade e análises comparativas do componente lenhoso de um remanescente de cerrado na região Sudeste do Brasil). O presente estudo teve como objetivo realizar um levantamento florístico-estrutural da comunidade arbustivo-arbórea de um fragmento de cerrado sensu stricto no Estado de São Paulo e compará-lo com outras áreas de cerrado. Foram delimitadas 21 parcelas de $250 \mathrm{~m}^{2}$ cada onde as plantas com diâmetro basal do caule igual ou superior a $3 \mathrm{~cm}$ foram incluídas na amostragem. Foram registrados 3062 indivíduos pertencentes a 58 espécies e 34 famílias. Asteraceae apresentou o maior número de espécies (sete), seguida por Fabaceae e Myrtaceae (cinco cada). As espécies mais importantes foram Tibouchina stenocarpa e Anadenanthera falcata. A composição florística da área de estudo indica que esta pode ser considerada como uma transição entre cerrado e floresta estacional semidecídua. A comparação com outras áreas indicou que há considerável heterogeneidade florístico-estrutural nas áreas de cerrado e as análises multivariadas mostraram que as áreas comparadas se agruparam de acordo com sua posição geográfica e tipo de solo.

Palavras-chave: fitossociologia, savana, similaridade

\section{Introduction}

The Neotropics have the world's second largest area of savannas and open woodlands, and Brazil constitutes the south limit of the savannas distribution in the American continent (Furley 1999). The Brazilian savanna, called cerrado, originally occupied around two million $\mathrm{km}^{2}$ of the national territory, including continuous and disjunct areas (Coutinho 2002). Today, it is estimated to be reduced to about 1.05 millions $\mathrm{km}^{2}$ (MMA 2009).
The so called cerrado is formed by a vegetation complex which encompasses a series of physiognomies from open grasslands (campo limpo) to dense woodlands (cerradão), with three intermediate physiognomies: campo sujo, grassland with a scattering of shrubs and small trees; campo cerrado, where there are some more shrubs and trees but still a larger proportion of grassland; and cerrado (sensu stricto), where trees and shrubs dominate but with a fair amount of herbaceous vegetation (Coutinho 2002). Such diversity of physiognomies contributes

1. Programa de Pós-Graduação em Ciências Biológicas, Botânica. Universidade Estadual Paulista, Instituto de Biociências, Botânica

2. Universidade Estadual Paulista, Instituto de Biociências, Departamento de Botânica, Caixa Postal 510, 18618-000 Botucatu, SP, Brazil

3. Corresponding author: rita@ibb.unesp.br 
to the great richness of cerrado biome: more than 11,000 plant species have already been catalogued (Mendonça et al. 2008), and about half of them are endemic (Myers et al. 2000). Although it has been considered one of the 25 hotspots for global-scale conservation (Myers et al. 2000), cerrado still does not have legal instruments directed to its preservation (Durigan et al. 2004), and only $2.2 \%$ of its area are under legal protection (Klink \& Machado 2005).

The cerrado areas in São Paulo State, Southeastern Brazil, are included in the south limit of distribution of the cerrado biome, and its remnants are fragmented in this area, undergoing a rapid destruction process (Durigan et al. 2004). Approximately 1,625,225 ha of cerrado (around $88.5 \%$ of the original area) are estimated to have been destructed in a 40-year period at this region (Kronka et al. 2005). In spite of their distance from the core area, São Paulo cerrados are notably rich in species and, therefore, highly representative (Ratter et al. 2003). As cerrado plants are hardly conserved out of their natural habitat because cultivation techniques are unknown for most species, preservation of samples from this vegetation is probably the only way to assure its survival (Durigan et al. 2004).

In this context, floristic and structural inventories have been carried out in cerrado remnants at a higher frequency because they are fundamental to any action which aims at more effective management, recovering and conservation. In the region of Botucatu municipality, São Paulo State, there are some cerrado fragments of still unknown structure; an inventory of these fragments is thus needed before they suffer more drastic interference.

The present study aimed at carrying out a floristic-structural analysis of the shrubby-arboreal component of a cerrado sensu stricto fragment in Botucatu municipality, São Paulo State, Brazil, and also to compare the studied fragment with some other cerrado areas, in order to answer the following questions: 1) Are the flora and structure of these woody communities similar? 2) Are the inventoried species in Botucatu area peculiar to cerrado formations? 3) In the negative cases, are the floristic elements originated from the surrounding vegetation formations? Results can help select areas for the establishment of future conservation units and recovering projects of degraded cerrado areas in Botucatu region.

\section{Material and methods}

The present study was carried out in Botucatu municipality, located in the west-central region of São Paulo State, Southeastern Brazil. The area corresponds to a cerrado sensu stricto fragment, at

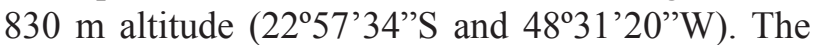
climate of the region is Cfa according to Koeppen classification (Cunha \& Martins 2009), and the soil in the area is Red-Yellow Latosol, according to the Brazilian System of Soil Classification (EMBRAPA 1999).

Structural analysis was carried out from January 2004 to April 2005, and 21 contiguous plots of 25 $\mathrm{m} \times 10 \mathrm{~m}$ each were laid out. In each plot, plants with stem basal diameter (SBD) equal or superior to $3 \mathrm{~cm}$ were marked and identified, followed by diameter measurement and height assessment. Dead individuals were considered as a single group, independent of their identification.

For the structural analysis, density, dominance and frequency (in relative terms) and importance value index (IV) were calculated for each species (Mueller-Dombois \& Ellenberg 1974). Biological diversity was assessed through Shannon-Wiener $\left(\mathrm{H}^{\prime}\right)$ and Equitability (J) indexes (Krebs 1989). All calculations were done by using the FITOPAC 1 software (Shepherd 1995). The spatial patterning in populations with two or more individuals was calculated by using the standardized Morisita Index of dispersion (Ip) which ranges from -1.0 to +1.0 , with $95 \%$ confidence limits at +0.5 and -0.5 (Krebs 1989). Random patterns give Ip of zero, clumped patterns above zero and uniform patterns below zero. However, we assumed that values very close to zero express random pattern.

All the identified species were also characterized in relation to their ability to occupy different phytocenoses. The species database was the lists found in Mendonça et al. (1998), Durigan et al. (2004) and Barbosa \& Martins (2008). The species were arranged according to the APG II taxonomic system as presented in Souza \& Lorenzi (2008). Voucher specimens were deposited in the Herbarium BOTU (Herbário Irina Delanova Gemtchujnicov, Instituto de Biociências de Botucatu, UNESP).

Data from ten previously published quantitative surveys on cerrado sensu stricto vegetation (table 1 , figure 1) were joined to our data and used to elaborate matrixes for multivariate analysis, in which the woody species were considered variables and 


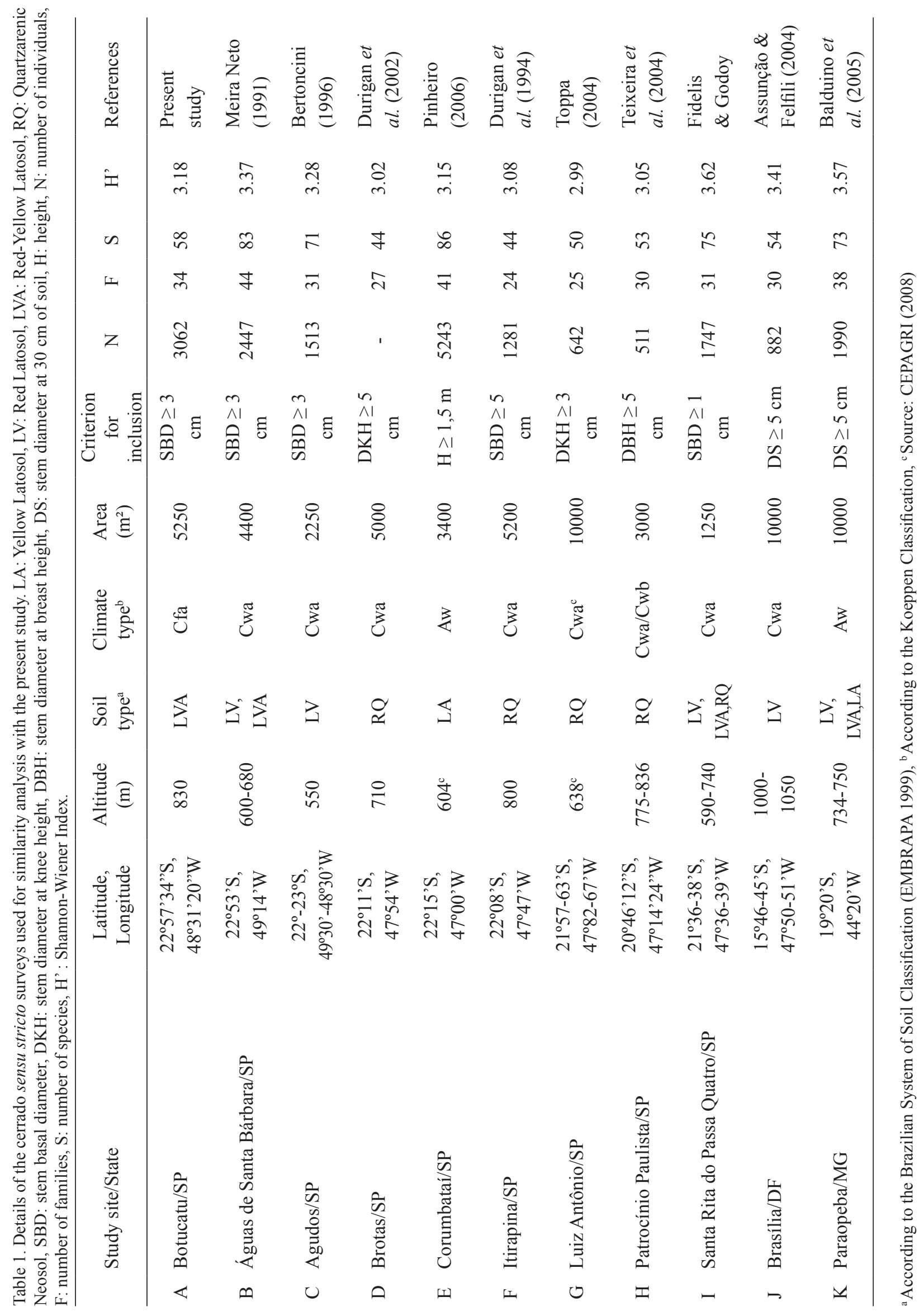




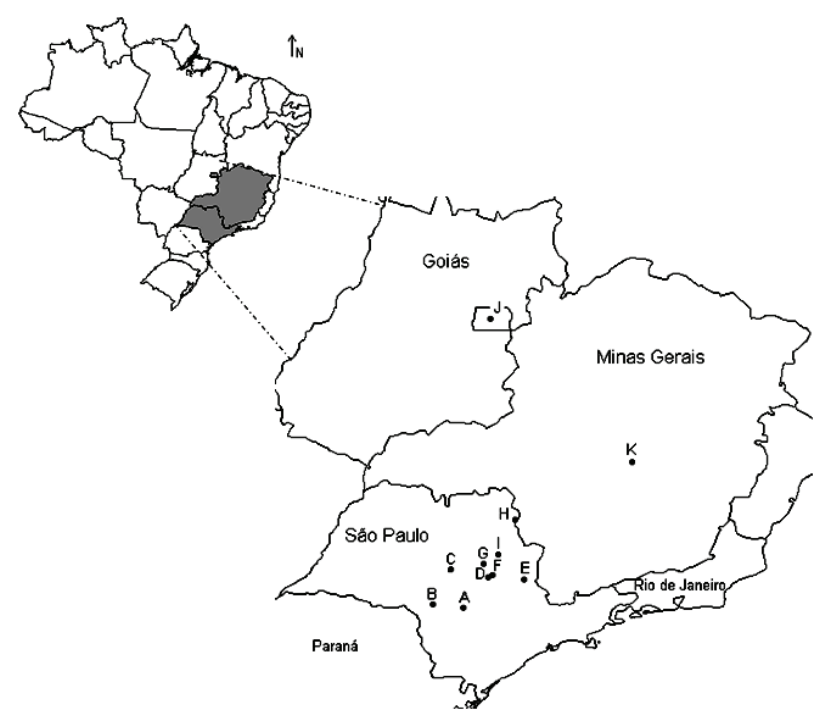

Figure 1. Map showing the locations of the present and previous study in areas of cerrado sensu stricto. The letters on the map correspond to those used in table 1.

the surveys were considered samples. Two of these surveys were performed in nuclear areas of cerrado, one located in the Federal District (Brasília) and other in Minas Gerais State. The other selected surveys were performed in São Paulo State and are marginal or disjunct cerrado areas (Ratter et al. 2003). These areas were selected in order to compare the floristic composition and structure of the studied cerrado aiming to investigate if there are peculiarities in that particular area, as pointed out initially.

The species in all study-sites and their importance value (IV) were used for the construction of the matrix in order to performed the Principal Components Analysis (PCA) and TWINSPAN classification (Two-Way Indicator Species Analysis) aiming to test the floristic and structural similarity among the surveys. The IV was used in these analyses since it gives good indications of the population structure of each species at each site (Felfili \& Silva Junior 1993). The species with incomplete identification (only genera, aff. or cf.) were not counted and the species present only in one area were also excluded, in accordance with methodology adopted by Ratter et al. (2003).

\section{Results}

A total of 3,062 individuals were sampled, including dead and undetermined ones. Fifty-eight species belonging to 34 families were registered but only 52 were identified to species level (table 2). The richest family was Asteraceae (seven species), followed by Fabaceae (five), Myrtaceae (five), Melastomataceae (four), and Erythroxylaceae (three). Together, they account for $41.38 \%$ of the surveyed species. Among the remaining families, seven were represented by two species each, and 22 were

Table 2. Structural parameters of species in cerrado sensu stricto area, Botucatu, São Paulo State, Brazil, orderly decreasing of IV (Importance Value). N: Number of Individuals, FR: Relative Frequency (\%), DR: Relative Density (\%), DoR: Relative Dominance (\%), Ip: Standardized Morisita Index of Dispersion, FT: Phytocenoses (C: cerrado, F: forest, C/F: cerrado and forest).

\begin{tabular}{|c|c|c|c|c|c|c|c|c|c|c|}
\hline & Species & Family & $\mathrm{N}$ & FR & DR & DoR & IV & Ip & $\begin{array}{l}\text { Spatial } \\
\text { Pattern }\end{array}$ & FT \\
\hline 1 & Tibouchina stenocarpa (DC.) Cogn. & Melastomataceae & 375 & 3.66 & 12.25 & 18.05 & 33.96 & 0.504 & clumped & $\mathrm{C} / \mathrm{F}$ \\
\hline 2 & Anadenanthera falcata (Benth.) Speg. & Fabaceae & 202 & 3.66 & 6.60 & 19.96 & 30.21 & 0.504 & clumped & $\mathrm{C} / \mathrm{F}$ \\
\hline 3 & Ouratea spectabilis (Mart. ex Engl.) Engl. & Ochnaceae & 279 & 3.66 & 9.11 & 6.74 & 19.51 & 0.500 & clumped & $\mathrm{C} / \mathrm{F}$ \\
\hline 4 & Rapanea umbellata (Mart.) Mez & Myrsinaceae & 288 & 3.48 & 9.41 & 5.61 & 18.50 & 0.566 & clumped & $\mathrm{C} / \mathrm{F}$ \\
\hline 5 & Dead individuals & - & 192 & 3.66 & 6.27 & 6.31 & 16.24 & 0.500 & clumped & - \\
\hline 6 & Myrcia guianensis (Aubl.) DC. & Myrtaceae & 230 & 3.66 & 7.51 & 3.59 & 14.76 & 0.502 & clumped & $\mathrm{C} / \mathrm{F}$ \\
\hline 7 & Dalbergia miscolobium Benth. & Fabaceae & 110 & 3.66 & 3.59 & 4.86 & 12.11 & 0.505 & clumped & $\mathrm{C}$ \\
\hline 8 & Eupatorium vauthierianum DC. & Asteraceae & 161 & 3.31 & 5.26 & 2.66 & 11.23 & 0.505 & clumped & $\mathrm{C} / \mathrm{F}$ \\
\hline 9 & Erythroxylum suberosum A. St.-Hil. & Erythroxylaceae & 137 & 3.48 & 4.47 & 1.66 & 9.62 & 0.509 & clumped & $\mathrm{C} / \mathrm{F}$ \\
\hline 10 & Acosmium subelegans (Mohlenbr.) Yakovlev & Fabaceae & 122 & 2.79 & 3.98 & 2.54 & 9.31 & 0.516 & clumped & $\mathrm{C}$ \\
\hline 11 & Myrcia lingua (O. Berg.) Mattos \& D. Legrand & Myrtaceae & 114 & 3.48 & 3.72 & 1.85 & 9.06 & 0.500 & clumped & $\mathrm{C}$ \\
\hline 12 & Schefflera vinosa (Cham. \& Schltdl.) Frodin \& Fiaschi & Araliaceae & 84 & 3.31 & 2.74 & 2.77 & 8.82 & 0.504 & clumped & $\mathrm{C}$ \\
\hline 13 & Piptocarpha rotundifolia (Less.) Baker & Asteraceae & 64 & 3.14 & 2.09 & 2.56 & 7.79 & 0.393 & clumped & $\mathrm{C}$ \\
\hline 14 & Rapanea guianensis Aubl. & Myrsinaceae & 67 & 3.31 & 2.19 & 1.23 & 6.73 & 0.568 & clumped & $\mathrm{C} / \mathrm{F}$ \\
\hline 15 & Guapira noxia (Netto) Lundell & Nyctaginaceae & 43 & 2.79 & 1.40 & 2.39 & 6.59 & 0.344 & clumped & $\mathrm{C} / \mathrm{F}$ \\
\hline
\end{tabular}




\begin{tabular}{|c|c|c|c|c|c|c|c|c|c|c|}
\hline & Species & Family & $\mathrm{N}$ & FR & DR & DoR & IV & Ip & $\begin{array}{l}\text { Spatial } \\
\text { Pattern }\end{array}$ & FT \\
\hline 16 & Erythroxylum tortuosum Mart. & Erythroxylaceae & 71 & 3.14 & 2.32 & 0.88 & 6.33 & 0.505 & clumped & $\mathrm{C}$ \\
\hline 17 & Gochnatia pulchra Cabrera & Asteraceae & 53 & 2.96 & 1.73 & 1.22 & 5.91 & 0.500 & clumped & $\mathrm{C} / \mathrm{F}$ \\
\hline 18 & Miconia albicans (Sw.) Triana & Melastomataceae & 36 & 2.44 & 1.18 & 1.27 & 4.88 & 0.205 & clumped & $\mathrm{C} / \mathrm{F}$ \\
\hline 19 & Stryphnodendron adstringens (Mart.) Coville & Fabaceae & 28 & 2.09 & 0.91 & 1.76 & 4.77 & 0.528 & clumped & $\mathrm{C} / \mathrm{F}$ \\
\hline 20 & Ocotea pulchella (Nees) Mez & Lauraceae & 39 & 2.61 & 1.27 & 0.70 & 4.59 & 0.179 & clumped & $\mathrm{C} / \mathrm{F}$ \\
\hline 21 & Miconia ligustroides (DC.) Naudin & Melastomataceae & 34 & 2.79 & 1.11 & 0.60 & 4.50 & 0.143 & clumped & $\mathrm{C} / \mathrm{F}$ \\
\hline 22 & Psidium pohlianum $\mathrm{O}$. Berg & Myrtaceae & 24 & 2.61 & 0.78 & 0.58 & 3.98 & -0.349 & uniform & $\mathrm{C}$ \\
\hline 23 & Campomanesia pubescens (DC.) O. Berg. & Myrtaceae & 35 & 2.44 & 1.14 & 0.34 & 3.93 & 0.451 & clumped & $\mathrm{C} / \mathrm{F}$ \\
\hline 24 & Zanthoxylum rhoifolium Lam. & Rutaceae & 26 & 2.44 & 0.85 & 0.59 & 3.88 & 0.087 & random & $\mathrm{C} / \mathrm{F}$ \\
\hline 25 & Psychotria sessilis Vell. & Rubiaceae & 23 & 2.61 & 0.75 & 0.34 & 3.70 & 0.061 & random & $\mathrm{C} / \mathrm{F}$ \\
\hline 26 & Byrsonima coccolobifolia Kunth & Malpighiaceae & 27 & 1.92 & 0.88 & 0.42 & 3.22 & 0.506 & clumped & $\mathrm{C}$ \\
\hline 27 & Styrax ferrugineus Nees \& Mart. & Styracaceae & 16 & 1.39 & 0.52 & 1.19 & 3.10 & 0.527 & clumped & $\mathrm{C} / \mathrm{F}$ \\
\hline 28 & Pouteria torta (Mart.) Radlk. & Sapotaceae & 23 & 0.70 & 0.75 & 1.56 & 3.01 & 0.865 & clumped & $\mathrm{C} / \mathrm{F}$ \\
\hline 29 & Pera glabrata (Schott) Poepp. ex Baill. & Peraceae & 14 & 1.74 & 0.46 & 0.71 & 2.91 & 0.070 & random & $\mathrm{C} / \mathrm{F}$ \\
\hline 30 & Qualea grandiflora Mart. & Vochysiaceae & 12 & 1.05 & 0.39 & 0.88 & 2.32 & 0.541 & clumped & $\mathrm{C}$ \\
\hline 31 & Aegiphila lhotszkyana Cham. & Lamiaceae & 12 & 1.74 & 0.39 & 0.17 & 2.30 & -0.192 & uniform & $\mathrm{C}$ \\
\hline 32 & Tabebuia ochracea (Cham.) Standl. & Bignoniaceae & 12 & 1.57 & 0.39 & 0.20 & 2.16 & -0.024 & random & $\mathrm{C} / \mathrm{F}$ \\
\hline 33 & Symplocos lanceolata A. DC. & Symplocaceae & 9 & 1.22 & 0.29 & 0.52 & 2.03 & 0.211 & clumped & $\mathrm{C} / \mathrm{F}$ \\
\hline 34 & Eriotheca gracilipes (K. Schum.) A. Robyns & Malvaceae & 6 & 0.70 & 0.20 & 0.58 & 1.48 & 0.510 & clumped & $\mathrm{C} / \mathrm{F}$ \\
\hline 35 & Lafoensia pacari A. St.-Hil. & Lythraceae & 7 & 1.05 & 0.23 & 0.15 & 1.43 & 0.000 & random & $\mathrm{C} / \mathrm{F}$ \\
\hline 36 & Gochnatia barrosii Cabrera & Asteraceae & 8 & 1.05 & 0.26 & 0.12 & 1.42 & 0.308 & clumped & $\mathrm{C}$ \\
\hline 37 & Erythroxylum cuneifolium (Mart.) O.E. Schulz. & Erythroxylaceae & 11 & 0.70 & 0.36 & 0.21 & 1.27 & 0.548 & clumped & $\mathrm{C} / \mathrm{F}$ \\
\hline 38 & Aspidosperma tomentosum Mart. & Apocynaceae & 11 & 0.70 & 0.36 & 0.20 & 1.25 & 0.723 & clumped & $\mathrm{C} / \mathrm{F}$ \\
\hline 39 & Caryocar brasiliense Cambess. & Caryocaraceae & 8 & 0.87 & 0.26 & 0.11 & 1.25 & 0.493 & clumped & $\mathrm{C}$ \\
\hline 40 & Piptocarpha axillaris (Less.) Baker & Asteraceae & 7 & 0.87 & 0.23 & 0.09 & 1.19 & 0.423 & clumped & $\mathrm{C} / \mathrm{F}$ \\
\hline 41 & Alibertia concolor (Cham.) K. Schum. & Rubiaceae & 6 & 0.70 & 0.20 & 0.25 & 1.15 & 0.317 & clumped & $\mathrm{C} / \mathrm{F}$ \\
\hline 42 & Leandra aurea (Cham.) Cogn. & Melastomataceae & 6 & 0.70 & 0.20 & 0.17 & 1.06 & 0.510 & clumped & $\mathrm{F}$ \\
\hline 43 & Vochysia tucanorum Mart. & Vochysiaceae & 7 & 0.70 & 0.23 & 0.11 & 1.03 & 0.518 & clumped & $\mathrm{C} / \mathrm{F}$ \\
\hline 44 & Plenckia populnea Reissek & Celastraceae & 4 & 0.70 & 0.13 & 0.16 & 0.98 & -0.144 & uniform & $\mathrm{C} / \mathrm{F}$ \\
\hline 45 & Arecaceae 1 & Arecaceae & 1 & 0.17 & 0.03 & 0.69 & 0.90 & - & - & - \\
\hline 46 & Piptocarpha macropoda (DC.) Baker & Asteraceae & 3 & 0.35 & 0.10 & 0.02 & 0.47 & 0.423 & clumped & $\mathrm{F}$ \\
\hline 47 & Jacaranda oxyphylla Cham. & Bignoniaceae & 2 & 0.35 & 0.07 & 0.01 & 0.42 & -0.048 & random & $\mathrm{C} / \mathrm{F}$ \\
\hline 48 & Vernonia polyanthes Less. & Asteraceae & 2 & 0.17 & 0.07 & 0.07 & 0.31 & 1.000 & clumped & $\mathrm{C} / \mathrm{F}$ \\
\hline 49 & Faboideae 1 & Fabaceae & 1 & 0.17 & 0.03 & 0.09 & 0.30 & - & - & - \\
\hline 50 & Daphnopsis utilis Warm. & Thymelaeaceae & 2 & 0.17 & 0.07 & 0.04 & 0.28 & 1.000 & clumped & $\mathrm{C} / \mathrm{F}$ \\
\hline 51 & Couepia grandiflora (Mart. \& Zucc.) Benth. ex Hook. f. & Chrysobalanaceae & 1 & 0.17 & 0.03 & 0.07 & 0.28 & - & - & $\mathrm{C} / \mathrm{F}$ \\
\hline 52 & Ocotea corymbosa (Meisn.) Mez & Lauraceae & 1 & 0.17 & 0.03 & 0.05 & 0.26 & - & - & $\mathrm{C} / \mathrm{F}$ \\
\hline 53 & Helietta sp. & Rutaceae & 1 & 0.17 & 0.03 & 0.02 & 0.23 & - & - & - \\
\hline 54 & Eugenia bimarginata DC. & Myrtaceae & 1 & 0.17 & 0.03 & 0.01 & 0.22 & - & - & $\mathrm{C} / \mathrm{F}$ \\
\hline 55 & Tournefortia paniculata Vent. & Boraginaceae & 1 & 0.17 & 0.03 & 0.01 & 0.22 & - & - & $\mathrm{C} / \mathrm{F}$ \\
\hline 56 & Unknown 1 & - & 1 & 0.17 & 0.03 & 0.01 & 0.22 & - & - & - \\
\hline 57 & Davilla elliptica A. St.Hil. & Dilleniaceae & 1 & 0.17 & 0.03 & 0.01 & 0.21 & - & - & $\mathrm{C}$ \\
\hline & Unknown 2 & - & 1 & 0.17 & 0.03 & 0.00 & 0.21 & - & - & - \\
\hline
\end{tabular}

monospecific. The Diversity and Equitability Indexes in the community were 3.176 and 0.782 , respectively.

The community total density was 5832.38 ind $\mathrm{ha}^{-1}$ (table 2). The species with the highest relative density was Tibouchina stenocarpa (12.25\%), followed by Rapanea umbellata $(9.41 \%)$, Ouratea spectabilis $(9.11 \%)$, Myrcia guianensis $(7.51 \%)$ and Anadenanthera falcata $(6.60 \%)$. Together, they account for $44.9 \%$ of the sampled individuals. The total basal area was $37.07 \mathrm{~m}^{2} \cdot \mathrm{ha}^{-1}$, and the highest values per species were observed for Anadenanthera falcata $\left(3.9 \mathrm{~m}^{2} \mathrm{ha}^{-1}\right)$ and Tibouchina 


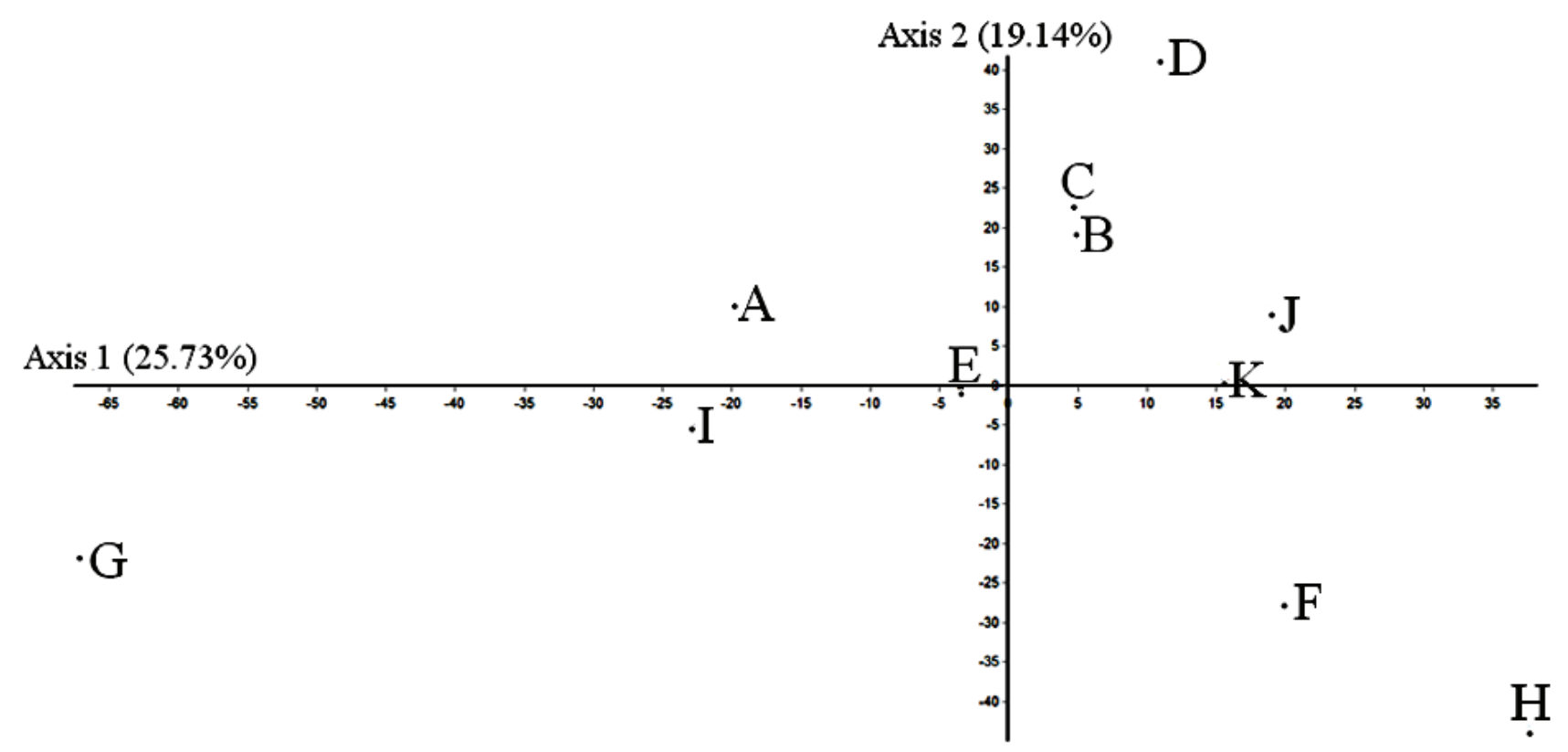

Figure 2. Principal Component Analysis (PCA) ordination diagram applied to species found in 11 surveys in cerrado sensu stricto. The letters correspond to those used in the map and in table 1.

stenocarpa $\left(3.5 \mathrm{~m}^{2} \mathrm{ha}^{-1}\right)$, the dominant species in the studied area.

The species with the highest IV, in decreasing order, were: Tibouchina stenocarpa, Anadenanthera falcata, Ouratea spectabilis, Rapanea umbellata, Myrcia guianensis, Dalbergia miscolobium, Eupatorium vauthierianum, Erythroxylum suberosum, Acosmium subelegans and Myrcia lingua. Together they are responsible for $56.09 \%$ of the total IV. If dead individuals were included, this value would increase to $61.50 \%$.

A larger concentration of individuals (45.75\%) was encountered in the smallest classes of diameters (3-6 cm), and the number of individuals decreased as diameter classes increased. Concerning the vertical structure, the largest concentration of individuals was registered in the $1-3 \mathrm{~m}$ height class $(63 \%), 20 \%$ of them belong to $3-4 \mathrm{~m}$ class, and only $12.3 \%$ were higher than this value, characterizing a discontinuous arboreal stratum, typical of cerrado sensu stricto. Few species reached the higher heights, especially Anadenanthera falcata $(8.5 \mathrm{~m})$, Pera glabrata $(8 \mathrm{~m})$, Ocotea corymbosa $(7 \mathrm{~m})$ and Pouteria torta $(7 \mathrm{~m})$.

The largest number of species $(n=39)$ had clumped spatial distribution, and the highest clump values were observed for Daphnopsis utilis, Vernonia polyanthes, Pouteria torta, Aspidosperma tomentosum, Rapanea guianensis and Rapanea umbellata. Random $(\mathrm{n}=6)$ and uniform $(\mathrm{n}=3)$ distribution were also registered but for few species (table 2).

Of the total of 52 identified species, $71.1 \%$ $(\mathrm{n}=37)$ can be found in cerrado and forest (semideciduous and/or riparian) areas, $25 \%(\mathrm{n}=13)$ are exclusively found in cerrado areas and $3.9 \%(n=2)$ are reported as exclusively found in forests (table 2).

The overall number of species sampled in all surveys compared was 238, excluding taxa not identified to species level. Of these identified species a total of 113 taxa were excluded because they occurred in only one survey, as recommended by methodology adopted. So, the final matrix included 125 species. Some of them had wide distribution and were registered in 10 of the 11 sites compared: Aspidosperma tomentosum, Erythroxylum suberosum, Ouratea spectabilis and Qualea grandiflora. These species had different importance value among the areas. For example, Ouratea spectabilis which occurs in all areas of São Paulo presented a range of IV between 5.30 and 25.32.

Some species were important in some areas and rare in others as Myrcia lingua that was one of the main species in Luiz Antônio (Toppa 2004), but rare in Brotas (Durigan et al. 2002). Acosmium subelegans was the most important species in Brotas (Durigan et al. 2002) and rare in Corumbataí (Pinheiro 2006). 
Daphnopsis fasciculata, Tibouchina stenocarpa and Vochysia parviflora were the most important species in Corumbataí (Pinheiro 2006), Botucatu (this study) and Minas Gerais (Balduino et al. 2005), respectively, and absent in all other areas.

In the PCA (figure 2), axis 1 was responsible for $25.73 \%$ of the information contained in all the variables and the axis 2 by $19.14 \%$, so the information accumulated by the first two principal components was $44.87 \%$. The variables with greater discriminatory value were Anadenanthera falcata (0.6868 ) in the first axis, leading to greater proximity of Botucatu, Luiz Antônio and Santa Rita do Passa Quatro surveys in the ordination space. Qualea grandiflora (- 0.6246) in the second axis influenced the location of Itirapina, Patrocínio Paulista, Luiz Antônio and Santa Rita do Passa Quatro. Acosmium subelegans showed high discriminatory value in the second axis (0.3486), defining the position of Brotas, Agudos, Águas de Santa Bárbara and Botucatu in the ordination space. The other areas showed an intermediary position.

The TWINSPAN analysis (figure 3) defined two major groups and showed a more coherent segregation pattern, considering the geographical position of the surveys. In the first division level, two groups were segregated, one composed of São Paulo cerrados and other formed by nuclear areas (Minas Gerais and Federal District). The divisions were strong with eigenvalues above 0.30 (Gauch 1982 apud Felfili et al. 2004). The preferential species to the nuclear areas were Agonandra brasiliensis, Enterolobium gummiferum, Erythroxylum deciduum, Eugenia dysenterica, Machaerium opacum, Schefflera macrocarpa, Sclerolobium paniculatum, species that were not found in the surveys in São Paulo. The São
Paulo surveys were finally divided into groups more similar to the spatial arrangement produced in the PCA analysis.

\section{Discussion}

The number of species observed in the studied cerrado is within the interval from 44 to 86 species reported in other cerrado at neighboring sites (table $1)$. This range may be due to different inclusion criterion adopted by the authors or to local variations related to environmental peculiarities or the degree of disturbance that the areas had undergone. However, the studied area showed to be highly distinct as Asteraceae is its richest family, a fact that was not observed in previous inventories performed in cerrados of Botucatu region (Silberbauer-Gottsberger \& Eiten 1987, Bicudo et al. 1996), which present Fabaceae, Myrtaceae in such position. This feature may be related to the conservation state of the studied cerrado considering that among the inventoried Asteraceae species Eupatorium vauthierianum (Maluf \& Wizentier 1998) and Vernonia polyanthes (Lorenzi 2008) are reported as colonizer species and Piptocarpha axilaris (Lorenzi 2009) and P. rotundifolia (Lorenzi 1998) are reported as pioneers in cerrado and forest areas.

The obtained diversity value $\left(H^{\prime}=3.18\right)$ is similar to others found in some areas of cerrado sensu stricto, in São Paulo State (table 1), within the same range as that of Federal District cerrados (Assunção \& Felfili 2004).

Density and basal area per hectare were among the highest values recorded in the region. The basal area value $\left(37.07 \mathrm{~m}^{2} \mathrm{ha}^{-1}\right)$ was similar to those obtained in other neighboring cerrado areas like $42.72 \mathrm{~m}^{2} \mathrm{ha}^{-1}$

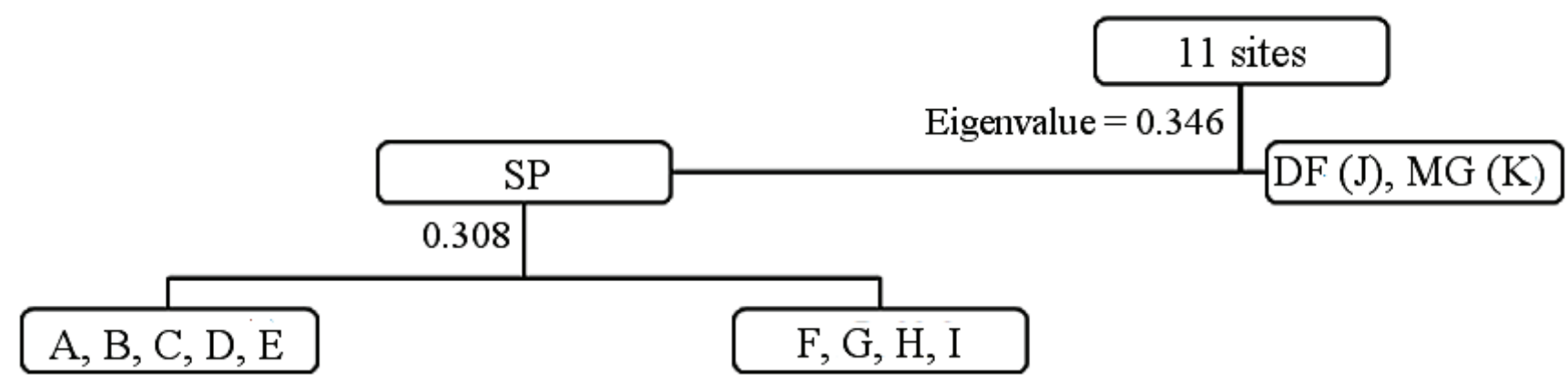

Figure 3. Classification by TWINSPAN applied to species found in 11 surveys in cerrado sensu stricto. The letters correspond to those used in the map and in table 1. 
found by Cavassan et al. (1993) in cerradão, 42.83 $\mathrm{m}^{2} / \mathrm{ha}^{-1}$ found by Bertoncini (1996) in cerrado sensu stricto and $48.27 \mathrm{~m}^{2} \mathrm{ha}^{-1}$ found by Faraco (2007) in cerradão. The basal area obtained for some other inventories was inferior to these values (see Cesar et al. 1988, Fidelis \& Godoy 2003, Assunção \& Felfili 2004, Balduino et al. 2005, all related to cerrado sensu stricto areas). These results may be related to the fact that the cerrados with higher values of basal area are frequently close or transitions to forest or cerradão areas, which generally show greater values to this parameter (see discussion in Cavassan et al. 1993, Bertoncini 1996, Faraco 2007).

The community diametric distribution showed a higher concentration of plants in the lowest classes, which can indicate that there is a great quantity of new individuals and that the community is probably undergoing an auto-regeneration phase (Assunção \& Felfili 2004). However, in the case of cerrado, it must also be considered that some species present short adults, which is their maximum genetic potential expression (Silva Junior \& Silva 1988).

The highest IV was observed for Tibouchina stenocarpa due to its high dominance value resultant from the large number of its individuals. Such feature is uncommon as this species rarely appears in other structural studies. It was recorded by Pereira-Silva et al. (2004) in Luiz Antônio (São Paulo State), with low importance value (0.61). This species is considered a pioneer in Botucatu region, present in areas with different degradation degrees (Sartor 1994). According to Durigan et al. (2004), it occurs in different cerrado physiognomies and in riparian forests. Besides, T. stenocarpa can be associated not only with disturbed vegetation but also with higher water availability in the soil, as its presence in more humid areas was reported by Pinto et al. (2005).

The second most important species in the community was Anadenanthera falcata, more frequently reported among those of high IV in cerrado areas (Fidelis \& Godoy 2003, Toppa 2004, Pinheiro 2006). Although this species was less abundant than Tibouchina stenocarpa, its representatives had larger basal area, leading therefore to high dominance.

Among the ten species with the highest IV, only the bush Eupatorium vauthierianum is not commonly reported in cerrado structural studies. This species had an IV of 0.65 in a cerradão area in Corumbataí, São Paulo State (Cesar et al. 1988). However, it was abundant in a region of poor and acid soil, in Santo André (São Paulo State), which underwent anthropic interferences, and was considered an r-strategist colonizer species (Maluf \& Wizentier 1998). Thus, its occurrence may evidence the regeneration phase now experienced by the studied area which, although preserved since year 2001, might have suffered anthropic interferences in the past since it is located beside a highway and an abandoned reforestation area. This may have contributed to some changes in the vegetation, favoring the establishment of pioneer species.

The particular feature of the studied cerrado where predominate species that are encountered both in cerrado and forest areas may indicate the occurrence of past immigration of forest species, since the area has being protected from fire for several years. Species like Alibertia concolor, Guapira opposita, Lafoensia pacari, Miconia ligustroides, Ocotea corymbosa, Ocotea pulchella, Pera glabrata, Platypodium elegans, Qualea multiflora, Rapanea umbellata, Solanum variabile, Tibouchina stenocarpa and Vochysia tucanorum have been previously reported in seasonal semi-deciduous forest in Botucatu region (Grombone-Guaratini \& MaimoniRodella 1995). Although the studied cerrado may be easily distinguished from forest formations by its physiognomy, its floristic composition indicates that the area might be considered a transition from cerrado to seasonal semi-deciduous forest. This situation was demonstrated by Pinheiro \& Monteiro (2006) who had pointed out that in absence of periodical fire some cerrado formations undergo secondary succession, leading to the establishment of forest ecosystems in ecotone areas. Considering that a seasonal semi-deciduous forest is located in the neighborhood, this hypothesis seems plausible. Besides, cerrados in marginal or disjunct areas are known to gradually grade to other formations and, as a consequence, show considerable floristic richness (Castro et al. 1999, Durigan \& Ratter 2006).

The most abundant species showed clumped spatial distribution, which could be a reflex of the existence of spots more favorable to their development, leading to higher concentration of individuals in these sites (Ludwig \& Reynolds 1988). According to Durigan et al. (2002), the high clumping rate of some species may also be associated with their regeneration form, and many cerrado species can regenerate by sprouting from subterranean structures. However, there is no available information on the species present in the studied area, except for Stryphnodendron adstringens and Aegiphla 
lhotszkyana, which can propagate from subterranean systems (Rizzini \& Heringer 1966). In São Paulo State cerrados, clumped spatial distribution seems to be the most common pattern, followed by uniform and random patterns, which normally occur at lower proportions (Durigan et al. 2002).

The ordination of the compared sites obtained by PCA analysis produced results that show greater proximity among areas with some degree of disturbance as Itirapina, Brasília and Paraopeba. The cerrado of Patrocínio Paulista, which is a reserve, was close to these areas probably due to the inclusion criterion adopted, resulting in a more reduced inventory. The ordination of the other areas may be related to soil characteristics, considering that the soil type is Quartzarenic Neosol in all sites with negative ordination in Axis 2. The remaining São Paulo areas, which are distributed in the positive region of Axis 2 present Red or Yellow Latosol (except Brotas).

The TWINSPAN classification was more related to geographical distribution, since the São Paulo areas were separated from the Minas Gerais and Federal District areas, forming two different groups. Similar results were obtained by Ratter et al. (2003). This analysis seems to be more reliable than others in the comparison of plant communities (Scudeller et al. 2001) and corroborates the statement that São Paulo State holds one of the cerrado centers of diversity whose floristic composition is different from the other cerrado diversity centers in Brazil (Ratter et al. 1996, Durigan et al. 2003, Gomes et al. 2004). Additionally, this analysis produced the same classification for São Paulo areas as observed in PCA analysis, segregating sites with Quartzarenic Neosol from areas with Latosol.

The peculiarities of the cerrado structure in Botucatu confirm the extreme variability of this vegetation even in restrict geographic areas, indicating the formation of regional vegetation mosaics, as previously reported for other cerrado biome areas (Bridgewater et al. 2004). The high diversity observed in that small sampled area reveals the importance of such fragments which, although altered, can be considered a remnant of the original vegetation, serving as floristic-structural reference for future conservation actions in the region. As stated by Assunção \& Felfili (2004), its maintenance is essential, mainly if we consider its role in the connection with other fragments, allowing pollen flow and seed dispersion among close areas. In addition, data obtained until the present moment can be useful for a better understanding of the structure and dynamics of the community, contributing therefore to future actions of conservation and rational sustainable exploitation.

\section{Acknowledgements}

The authors thank to Y.A.N.P. Yanagizawa for valuable suggestions to the project, to G.F.G. Déstro for field assistance, to C. Campos for preliminary identification of some species and to CentrofloraAnidro do Brasil Company for research license. This work is part of the master's dissertation of the fist author supported by Coordenação deAperfeiçoamento de Pessoal de Nível Superior (CAPES).

\section{Literature cited}

Assunção, S.L. \& Felfili, J.M. 2004. Fitossociologia de um fragmento de cerrado sensu stricto na APA do Paranoá, DF, Brasil. Acta Botanica Brasilica 18: 903-909.

Balduino, A.P.C., Souza, A.L., Meira Neto, J.A.A., Silva, A.F. \& Silva Junior, M.C. 2005. Fitossociologia e análise comparativa da composição florística do cerrado da flora de Paraopeba-MG. Revista Árvore 29: 25-34.

Barbosa, L.M. \& Martins, S.E. 2008. Espécies arbóreas nativas: indicação por região e ecossistema do Estado de São Paulo. http:// www.ibot.sp.gov.br/especie_arborea/especies arboreas.htm (accessed in 24.12.2008).

Bertoncini, A.P. 1996. Composição florística e estrutura fitossociológica de uma área de cerrado no município de Agudos-SP. Master's Dissertation, Universidade Estadual Paulista, Botucatu.

Bicudo, L.R.H., César, O. \& Monteiro, R. 1996. Florística comparativa de uma área de cerrado no Município de Botucatu, SP (Brasil). Arquivos de Biologia e Tecnologia 39: 685-691.

Bridgewater, S., Ratter, J.A. \& Ribeiro, J.F. 2004. Biogeographic patterns, $\beta$-diversity and dominance in the cerrado biome of Brazil. Biodiversity and Conservation 13: 2295-2318.

Castro, A.A.J.F., Martins, F.R., Tamashiro, J.Y. \& Shepherd, G.J. 1999. How rich is the flora of Brazilian cerrados? Annals of the Missouri Botanical Garden 86: 192-226.

Cavassan, O., Paschoal, M.E.S., Coral, D.J. \& Sodré, C. 1993. Levantamento fitossociológico 
do estrato arbustivo-arbóreo de uma área com vegetação nativa na fazenda Monte Alegre no município de Agudos-SP. Salusvita 12: 127-144.

CEPAGRI, Centro de Pesquisas Meteorológicas e Climáticas Aplicado à Agricultura. 2008. Clima dos municípios paulistas. http://www.cpa. unicamp.br (accessed in 27.12.2008).

Cesar, O., Pagano, S.N., Leitão Filho, H.F., Monteiro, R., Silva, A.O., Marinis, G. \& Shepherd, G.J. 1988. Estrutura fitossociológica do estrato arbóreo de uma área de vegetação de cerrado no município de Corumbataí (Estado de São Paulo). Naturalia 13: 91-101.

Coutinho, L.M. 2002. O bioma cerrado. In: A.L. Klein (org.). Eugen Warming e o cerrado brasileiro: um século depois. Editora UNESP, São Paulo, pp. 77-91.

Cunha, A.R. \& Martins, D. 2009. Classificação climática para os municípios de Botucatu e São Manuel, SP. Irriga 14: 1-11.

Durigan, G., Baitello, J.B., Franco, G.A.D.C. \& Siqueira, M.F. 2004. Plantas do cerrado paulista: imagens de uma paisagem ameaçada. Páginas e Letras Editora e Gráfica, São Paulo.

Durigan, G., Leitão Filho, H.F. \& Rodrigues, R.R. 1994. Phytosociology and structure of a frequently burnt cerrado vegetation in SE-Brazil. Flora 189: 153-160.

Durigan, G., Nishikawa, D.L.L., Rocha, E., Silveira, E.R., Pulitano, F.M., Regalado, L.B., Carvalhaes, M.A., Paranaguá, P.A. \& Ranieri, V.E.L. 2002. Caracterização de dois estratos da vegetação em uma área de cerrado no município de Brotas, SP, Brasil. Acta Botanica Brasilica 16: 251-262.

Durigan, G. \& Ratter, J.A. 2006. Successional changes in cerrado and cerrado/forest ecotonal vegetation in western São Paulo State, Brazil, 1962-2000. Edinburgh Journal of Botany 63: 119-130.

Durigan, G., Ratter, J.A., Bridgewater, S., Siqueira, M.F. \& Franco, G.A.D.C. 2003. Padrões fitogeográficos do cerrado paulista sob uma nova perspectiva regional. Hoehnea 30: 39-51.

EMBRAPA. 1999. Sistema brasileiro de classificação de solo. Empresa Brasileira de Pesquisa Agropecuária. Centro Nacional de Pesquisa de Solos, Rio de Janeiro.

Faraco, A.G. 2007. Composição florística e estrutura fitossociológica de uma área de cerrado pertencente ao Campus de Bauru da
Universidade estadual Paulista, UNESP, SP. Master's Dissertation, Universidade Estadual Paulista, Botucatu.

Felfili, J.M. \& Silva Junior, M.C. 1993. A comparative study of cerrado (sensu stricto) vegetation in Central Brazil. Journal of Tropical Ecology 9: 277-289.

Felfili, J.M., Silva Junior, M.C., Sevilha, A.C., Fagg, C.W., Walter, B.M.T., Nogueira, P.E. \& Rezende, A.V. 2004. Diversity, floristic and structural patterns of cerrado vegetation in Central Brazil. Plant Ecology 175: 37-46.

Fidelis, A. \& Godoy, S.A.P. 2003. Estrutura de um cerrado stricto sensu na Gleba Cerrado Pé-deGigante, Santa Rita do Passa Quatro, SP. Acta Botanica Brasilica 17: 531-539.

Furley, P.A. 1999. The nature and diversity of neotropical savanna vegetation with particular reference to the Brazilian cerrados. Global Ecology and Biogeography 8: 223-241.

Gomes, B.Z., Martins, F.R. \& Tamashiro, J.Y. 2004. Estrutura do cerradão e da transição entre cerradão e floresta paludícola num fragmento da International Paper do Brasil Ltda., em Brotas, SP. Revista Brasileira de Botânica 27: 249-262.

Grombone-Guaratini, M.T. \& Maimoni-Rodella, R.C.S. 1995. Levantamento florístico em área de vegetação residual em Rubião Júnior, município de Botucatu, SP. Arquivos de Biologia e Tecnologia 38: 917-925.

Klink, C.A. \& Machado, R.B. 2005. Conservation of the Brazilian Cerrado. Conservation Biology 19: 707-713.

Krebs, C.J. 1989. Ecological Methodology. Harper and Row, New York.

Kronka, F.J.N., Nalon, M.A., Matsukuma, C.K., Kanashiro, M.M., Ywane, M.S.S., Pavão, M., Durigan, G., Lima, L.M.P.R., Guillaumon, J.R., Baitello, J.B., Borgo, S.C., Manetti, L.A., Barradas, A.M.F., Fukuda, J.C., Shida, C.N., Monteiro, C.H.B., Pontinha, A.A.S., Andrade, G.G., Barbosa, O. \& Soares, A.P. 2005. Inventário florestal da vegetação natural do Estado de São Paulo. Instituto Florestal, São Paulo.

Lorenzi, H. 1998. Árvores brasileiras: manual de identificação e cultivo de plantas arbóreas nativas do Brasil, v. 2. Editora Plantarum, Nova Odessa.

Lorenzi, H. 2008. Plantas daninhas do Brasil: terrestres, aquáticas, parasitas e tóxicas. Instituto Plantarum, Nova Odessa. 
Lorenzi, H. 2009. Árvores brasileiras: manual de identificação e cultivo de plantas arbóreas nativas do Brasil, v. 3. Editora Plantarum, Nova Odessa.

Ludwig, J.A. \& Reynolds, J.F. 1988. Statistical Ecology: a primer on methods and computing. John Wiley and Sons, New York.

Maluf, A.M. \& Wizentier, B. 1998. Aspectos fenológicos e germinação de sementes de quatro populações de Eupatorium vauthierianum DC. (Asteraceae). Revista Brasileira de Botânica 21: 247-251.

Meira Neto, J.A.A. 1991. Composição florística e fitossociologia de fisionomias de vegetação de cerrado sensu lato da Estação Ecológica de Santa Bárbara (E.E.S.B.), município de Águas de Santa Bárbara, estado de São Paulo. Master's Dissertation, Universidade Estadual de Campinas, Campinas.

Mendonça, R.C., Felfili, J.M., Walter, B.M.T., Silva Junior, M.C., Rezende, A.V., Filgueiras, T.S. \& Nogueira, P.E. 1998. Flora vascular do cerrado. In: S.M. Sano \& S.P. Almeida (eds.). Cerrado: ambiente e flora. Embrapa, Brasília, pp. 289-556.

Mendonça, R.C., Felfili, J.M., Walter, B.M.T., Silva Junior, M.C., Rezende, A.V., Filgueiras, T.S., Nogueira, P.E. \& Fagg, C.W. 2008. Flora vascular do bioma cerrado: checklist com 12.356 espécies. In: S.M. Sano, S.P. Almeida \& J.F. Ribeiro (eds.). Cerrado: ecologia e flora, v. 2. Embrapa, Brasília, pp. 422-442.

MMA. 2009. Relatório Técnico de Monitoramento do Desmatamento no Bioma Cerrado, 2002 a 2008: dados revisados. Ministério do Meio Ambiente, Brasília.

Mueller-Dombois, D. \& Ellenberg, H. 1974. Aims and methods of vegetation ecology. John Wiley and Sons, New York.

Myers, N., Mittermeier, R.A., Mittermeier, C.G., Fonseca, G.A.B. \& Kent, J. 2000. Biodiversity hotspots for conservation priorities. Nature 403: 853-858.

Pereira-Silva, E.F.L., Santos, J.E., Kageyama, P.Y. \& Hardt, E. 2004. Florística e fitossociologia dos estratos arbustivo e arbóreo de um remanescente de cerradão em uma Unidade de Conservação do Estado de São Paulo. Revista Brasileira de Botânica 27: 533-544.

Pinheiro, M.H.O. 2006. Composição e estrutura de uma comunidade savânica em gradiente topográfico no município de Corumbataí (SP,
Brasil). Doctor's Thesis, Universidade Estadual Paulista, Rio Claro.

Pinheiro, M.H.O.\& Monteiro, R. 2006. Contribution of forest species to the floristic composition of a forested savanna in Southeastern Brazil. Brazilian Archives of Biology and Technology 49: 763-774.

Pinto, L.V.A., Davide, A.C., Botelho, A.S., Oliveira-Filho, A.T. \& Machado, E.L.M. 2005. Distribuição das espécies arbóreoarbustivas ao longo do gradiente de umidade do solo de nascentes pontuais da Bacia Hidrográfica do Ribeirão Santa Cruz, Lavras, MG. Cerne 11: 294-305.

Ratter, J.A., Bridgewater, S., Atkinson, R. \& Ribeiro, J.F. 1996. An analysis of the floristic composition of the Brazilian cerrado vegetation: comparison of the woody vegetation of 98 areas. Edinburgh Journal of Botany 53: 153-180.

Ratter, J.A., Bridgewater, S. \& Ribeiro, J.F. 2003. Analysis of the floristic composition of the Brazilian cerrado vegetation III: comparison of the woody vegetation of 376 areas. Edinburgh Journal of Botany 60: 57-109.

Rizzini, C.T. \& Heringer, E.P. 1966. Estudo sobre os sistemas subterrâneos difusos de plantas campestres. Anais da Academia Brasileira de Ciências 38: 85-112.

Sartor, M.B.L.B. 1994. Fenologia e biologia floral de Miconia albicans (Sw.) Triana e Tibouchina stenocarpa (DC.) Cogn. (Melastomataceae). Master's Dissertation, Universidade Estadual Paulista, Botucatu.

Scudeller, V.V., Martins, F.R. \& Shepherd, G.J. 2001. Distribution and abundance of arboreal species in the atlantic ombrophilous dense forest in Southeastern Brazil. Plant Ecology 152: 185-199.

Shepherd, G.J. 1995. FITOPAC 1, Manual de usuário. Departamento de Botânica, Universidade Estadual de Campinas, Campinas.

Silberbauer-Gottsberger, I. \& Eiten, G. 1987. A hectare of cerrado. I. General aspects of the trees and thick-stemmed shrubs. Phyton 27: 55-91.

Silva Junior, M.C. \& Silva, A.F. 1988. Distribuição dos diâmetros dos troncos das espécies mais importantes do cerrado na Estação Florestal de Experimentação de Paraopeba (EFLEX)-MG. Acta Botanica Brasilica 2: 107-126.

Souza, V.C. \& Lorenzi, H. 2008. Botânica sistemática: guia ilustrado para identificação das famílias de fanerógamas nativas e exóticas 
no Brasil, baseado em APG II. 2 ed. Instituto Plantarum, Nova Odessa.

Teixeira, M.I.J.G., Araújo, A.R.B., Valeri, S.V. \& Rodrigues, R.R. 2004. Florística e fitossociologia de área de cerrado s.s. no município de Patrocínio Paulista, nordeste do estado de São Paulo. Bragantia 63: 1-11.

Toppa, R.H. 2004. Estrutura e diversidade florística das diferentes fisionomias de cerrado e suas correlações com o solo na Estação Ecológica de Jataí, Luiz Antônio, SP. Doctor's Thesis, Universidade Federal de São Carlos, São Carlos. 